\title{
A NOVEL TREATMENT BY GRAPHENE-BASED NANOMATERIALS AND 6-BENZYLAMINOPURINE TO IMPROVE FLOWERING AND CORM PRODUCTION OF GLADIOLUS GRANDIFLORUS ANDREWS 'WHITE PROSPERITY'
}

\author{
O.H. Tawfik ${ }^{*}$ and O.H.M. Ibrahim ${ }^{* * * * * *}$ \\ * Department of Horticulture, Faculty of Agriculture, Al-Azhar University, Assiut Branch, Egypt \\ ** Department of Arid Land Agriculture, Faculty of Meteorology, Environment and Arid Land \\ Agriculture, KAU, KSA \\ *** Department of Ornamental Plants and Landscape Gardening, Faculty of Agriculture, Assiut \\ University, Egypt
}

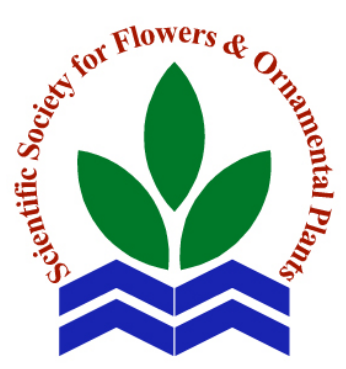

Scientific J. Flowers \& Ornamental Plants, 8(1):195-208 (2021).

Received:

$15 / 2 / 2021$

Accepted:

$22 / 3 / 2021$

Corresponding author: O.H.M. Ibrahim omer.ibrahim@aun.edu.eg

ABSTRACT: Graphene-based nanomaterials have great potential to improve cut flower production, including the production of highquality corms of gladiolus locally to compensate for the shortage in imported corms mostly from the Netherlands due to the recent unprecedented global spread of COVID-19. In this study, we investigated the response of the cultivar 'White Prosperity' to various doses of nano-carbon as graphene oxide nanomaterials $(0,3,5$ and 7 $\mathrm{g} / \mathrm{l})$ in combination with BA $(0,50,75$ and $100 \mathrm{mg} / \mathrm{l})$. The results demonstrated that the combination of the medium or the high BA concentrations (50 and $75 \mathrm{mg} / \mathrm{l}$ ), with these of nano-carbon (5 and 7 $\mathrm{g} / \mathrm{l})$ promoted good vegetative and flowering growth. Pearson's product correlation showed positive relationships between all the tested parameters except for the number of days to flowering, which negatively correlated with all the traits. These results were further confirmed by PCA results. Our findings provide evidence that nanocarbon can render positive effects on flowering and corm production of gladiolus that may be applicable for other important flower bulb species.

Key words: Gladiolus grandiflorus, nano-carbon, nanotechnology, flower bulbs, sword lily.

\section{INTRODUCTION}

Flowering bulbs have high importance to the worldwide cut flower production. They have gained their importance from their utilization as fresh cut flowers, pot plants or as garden landscaping elements. Gladiolus is one of seven flower bulb genera dominating the industry of cut flower production (Benschop et al., 2010). It is one of 106 genera belonging to the family Iridaceae and native to South Africa, which is known as sword lily referring to its sword-like shape leaves. In addition to its importance as a famous cut flower for floral arrangements, it is grown in flower beds (Lepcha et al., 2007). Due to the noticeable increase in the global demand for gladiolus and other flower bulbs, new flower production centers have been developed such as Latin America, Africa, and Asia and much effort is needed in the field of production (Benschop et al., 2010). In many countries, high-quality gladiolus corms are annually imported from abroad, mostly from the Netherlands. With the recent unprecedented global spread of COVID-19, questions regarding the pandemic's impact on exports and imports have become hot topics in the world. This led to raising the prices of corms or the unavailability of the imported corms, which encouraged us to study some innovative factors that may help in producing the corms 


\section{O.H. Tawfik and O.H.M. Ibrahim}

locally including the application of graphene-based nanomaterials and BA.

The effectiveness of chemicals such as cytokinins in the cultivation and production of gladiolus has been studied extensively mainly to accelerate the flowering, increase the flower yield and improve flower quality (Ram et al., 2002). Benzyl adenine is a cytokinin reported to be useful for enhancing sprouting, increasing sprouts per plant and thereby yield of corms, yet the treatment efficacy varies with chemical type, cultivar, and other factors (Roy et al., 2017). Engineered nanomaterials including carbonbased nanomaterials are promising candidates for use in the agricultural field. Most of the studies conducted on the application of nanomaterials in the agricultural field have dealt with their toxicity to plants, mammalians and the ecosystem (Park et al., 2020). There are several types of carbon-based nanomaterials including graphene, graphene oxide nanosheets, reduced graphene oxide and chemically modified graphene (Shareena et al., 2018). Graphene oxide nanosheets (GNS) are widely investigated in many fields such as medicine, chemistry and environmental protection Meanwhile there are few published studies discussing the effect of GNS on plants (Novoselov et al., 2012 and Yin et al., 2018). Fortunately, biosafety of graphene nanosheets has been reported by several authors such as $\mathrm{Hu}$ et al. (2010). To emphasize biosafety, there is a need as well to realize the interactions between GNS and plants. In this regard, Serag et al. (2015) revealed favorable results of GNS on plants. Likewise, Younes et al. (2019) proved with great evidence the safety of GNS in boosting the growth and productivity of peppers and eggplants. Stimulation of plant growth has been achieved by other types of carbon-based nanomaterials involving carbon nanotubes (Khodakovskaya et al., 2012) and graphene quantum dots on coriander and garlic offering improved biological properties (Chakravarty et al., 2015). Another benefit of GNS is their use as a new carrier platform to organize nutrients absorption in the plant with controllable slow release. By the effective absorption of NPK and calcium, the nutrients loss rate is significantly reduced, leading to increasing total chlorophyll, a and $\mathrm{b}$ and thus promoting root growth and plant morphology (Kabiri et al., 2017 and Taha, 2016). Incorporation of nano-carbon with fertilizers could improve soil physical and chemical properties as proved by Wang et al. (2018) when urea was applied with nanocarbon.

Given the little information available about the influence of carbon-based nanomaterials on the productivity of cut flowers, it is important to determine the proper concentration of nanomaterials that induce the best growth and flowering of specific cultivars, which will certainly be of great benefit to the florists and commercial growers. Accordingly, an attempt is intended by the current study to incorporate BA and GNS at various concentrations and investigate their effect on the growth, flowering and corm production of gladiolus 'White Prosperity'. The anticipated results will provide a basis for utilizing carbon nanomaterials in the production of other important flower bulb species.

\section{MATERIALS AND METHODS}

The present study involved a field trial conducted at the nursery of Faculty of Agriculture, Al-Azhar University Assiut branch, Assiut, Egypt during the two successive seasons of 2018/2019 and 2019/2020 on the cultivar 'White Prosperity' of Gladiolus grandiflorus Andrews.

This experiment was arranged in a $4 \times 4$ two-way factorial experiment in a split-plot design with three replicates, each experimental unit comprised 10 plants with a total of 480 plants for the whole experiment. Two substances were employed including 6benzylaminopurine (BA) brought from S.D. Fine-Chem Limited, India and graphene nanosheets (nano-carbon), which was prepared as previously described by Ali et al. (2015). Treatments of BA, $(0,25,50$ and 75 
$\mathrm{mg} / \mathrm{l})$ were randomly assigned to the main plots, whereas the 4 treatments of nanocarbon, $(0,3,5$ and $7 \mathrm{~g} / \mathrm{l})$ were assigned to the sub-plots. Untreated plants (control) were sprayed with distilled water. Imported Precooled uniform corms of gladiolus 'White Prosperity' (8-10 $\mathrm{cm}$ circumference) were used in the two experimental seasons. The corms were planted under open field conditions on November $25^{\text {th }}$ of both seasons. Physical and chemical properties of the used soil were done according to the methods described by Black et al. (1965) and Jackson (1973) and listed in Table (1). The soil was prepared and divided into $100 \times 50$ $\mathrm{cm}$ beds oriented from East to West, each bed contained one furrow and represented an experimental unit. The corms were planted on one side of the furrow at a depth of about $7-8 \mathrm{~cm}$ and spaced $10 \mathrm{~cm}$ apart. Thus, every experimental unit contained 10 corms and every treatment contained 30 corms divided into 3 replicates. Treatments of both BA and nano-carbon were applied as foliar spray three times starting from 45 days after planting the corms and then applied two more times at 15-day intervals. One-day period was allowed between the application of BA and nano-carbon to avoid any leaching effect.

The plants were irrigated every 14 days until the beginning of March and then at 10day intervals until April $25^{\text {th }}$. Thereafter, the plants were kept till the digging date without irrigation to allow drying of the leaves and maturity of new corms and cormels. Every plant was fertilized as recommended with 8 $\mathrm{g}$ of ammonium sulfate $(20.6 \% \mathrm{~N}), 8 \mathrm{~g}$ calcium superphosphate $\left(15.5 \% \mathrm{P}_{2} \mathrm{O}_{5}\right)$ and 4 g potassium sulfate $\left(48 \% \mathrm{~K}_{2} \mathrm{O}\right)$ per plant. These quantities were applied as dressing beside each plant in four equal portions. The first was applied when the plants reached about $10-20 \mathrm{~cm}$ height (3 leaves stage), the second at mid of vegetative growth period, the third at the beginning of the appearance of inflorescence, while the fourth was immediately applied after picking the flowers in order to encourage the growth of corms and cormels.

At the end of each season, the data were recorded on plant height $(\mathrm{cm})$, number of days to flowering (number of days from planting to the first flower bud opening), flowering duration (days), spike length $(\mathrm{cm})$, rachis length $(\mathrm{cm})$, number of florets/spike, fresh weight of cut spike (estimated in grams as the fresh weight of cut stem bearing flowers), dry weight of cut spike (g), spike diameter (measured in $\mathrm{cm}$ at the base of stem after picking spikes). The basal part bearing four leaves was left to permit the growth of corms and cormels. The productivity of corms and cormels was evaluated by recording the fresh and dry weights of the produced corm $(\mathrm{g})$, corm diameter $(\mathrm{cm})$ and cormels yield (number of the produced cormels/plant).

Data obtained were statistically analyzed as ANOVA in split-plot design and the

Table 1. Some physical and chemical properties of the used soil (average of both seasons).

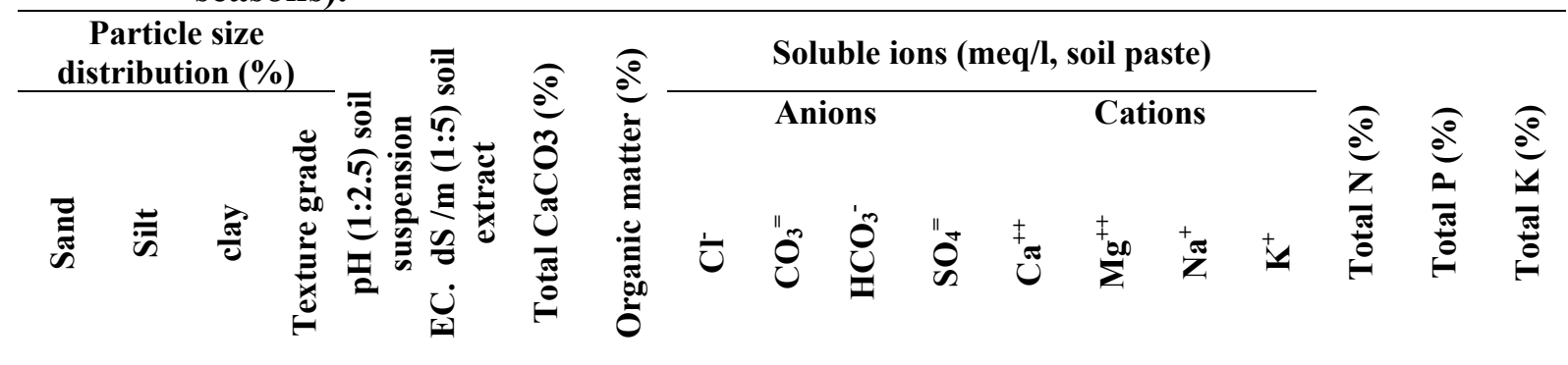

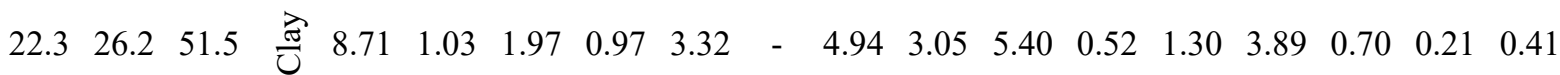




\section{O.H. Tawfik and O.H.M. Ibrahim}

means of the different treatments were compared using LSD test (the least significant difference) based on Gomez and Gomez (1984) using Statistix 8.1 (Analytical Software, 2008). Pearson's correlation coefficient and principal components analysis (PCA) were performed using Analyse-it Software (v. 5.6 for excel).

\section{RESULTS}

\section{Vegetative and flowering growth:}

To investigate the opportunities for enhancing vegetative and flowering growth of gladiolus 'White Prosperity', this experiment considered the application of BA and nano-carbon (graphene nanosheets) with the possible combinations of various concentrations. The results showed that vegetative and flowering growth parameters (except spike diameter, data not presented) had a significant variation in response to the applied treatments in both growing seasons as proved by two-way ANOVA at $\mathrm{p}<0.05$ (Figs., 1 and 2). Plant height showed a tendency to increase with increasing the concentration of BA and nano-carbon. The tallest plants appeared in response to the combination of the medium or the high concentrations of BA (50 and $75 \mathrm{mg} / \mathrm{l}$ ), and those of nano-carbon (5 and $7 \mathrm{~g} / \mathrm{l})$, respectively. The earliest flowering plants were those receiving the highest concentrations of both materials $(75 \mathrm{mg} / 1 \mathrm{BA}$ and $7 \mathrm{~g} / 1$ nano-carbon) and the time elapsed from planting to the first flower bud opening under this treatment was $123.8,123.2$ days in both seasons which was about 4 to 6 days earlier than the untreated plants or those treated with either of the two materials alone. The duration of the flowering season extended from 3 days in untreated plants to as long as 7.3 or 7.7 days, in both seasons, in those treated with the combination of BA at $50 \mathrm{mg} / 1$ and nano-carbon at $7 \mathrm{~g} / 1$.

Characteristics of the flowering spike varied in their response to the different treatments (Figs., 1 and 2), while no significant differences were detected in spike diameter. The lengths of both spike and rachis recorded the highest values when the treatment of BA at $50 \mathrm{mg} / \mathrm{l}$ was combined with nano-carbon at either 5 or $7 \mathrm{~g} / \mathrm{l}$. Application of nano-carbon at $3 \mathrm{~g} / 1$ alone or in combination with BA at $50 \mathrm{mg} / \mathrm{l}$ gave the highest number of florets per spike. Fresh and dry weights of the spike exhibited a similar trend during both growing seasons, where the plants treated with BA at either 50 or $70 \mathrm{mg} / \mathrm{l}$ combined with nano-carbon at either 5 or $7 \mathrm{~g} / 1$ produced the heaviest spikes.

\section{Corm and cormels production:}

All gladiolus 'White Prosperity' plants under study produced one new corm per plant, and therefore the data are not presented. However, the characteristics of the produced corm varied significantly among the treatments, mainly in terms of fresh and dry weights of corms (Fig., 3). The produced corms tended to be heavier with the increase in the concentration of BA reaching its heaviest fresh and dry weights at $50 \mathrm{mg} / \mathrm{l} \mathrm{BA}$ in combination with nanocarbon at $3 \mathrm{~g} / 1$ followed by $75 \mathrm{mg} / \mathrm{l} \mathrm{BA}$ with $7 \mathrm{~g} / 1$ nano-carbon in descending order in both seasons. The increment in corm weight induced by these treatments was more than $150 \%$ of that produced in the untreated plants. Corm diameter, on the other hand, was not a determining factor as no significant differences were detected. Another important factor in the production of gladiolus is the number of cormels/corm, which showed significant differences among treatments. The number of cormels/corm significantly increased with the increase in the concentration of both BA and nanocarbon, recording the highest number of cormels/corm when the highest concentrations of both materials $(75 \mathrm{mg} / 1 \mathrm{BA}$ and $7 \mathrm{~g} / 1$ nano-carbon) were applied in a combined treatment. These values exceeded 150 cormels per corm comparing to about 100 cormels in the untreated plants, which accounts for $150 \%$.

\section{Pearson's correlation coefficient:}

Pearson's product correlation between all the tested parameters showed positive 


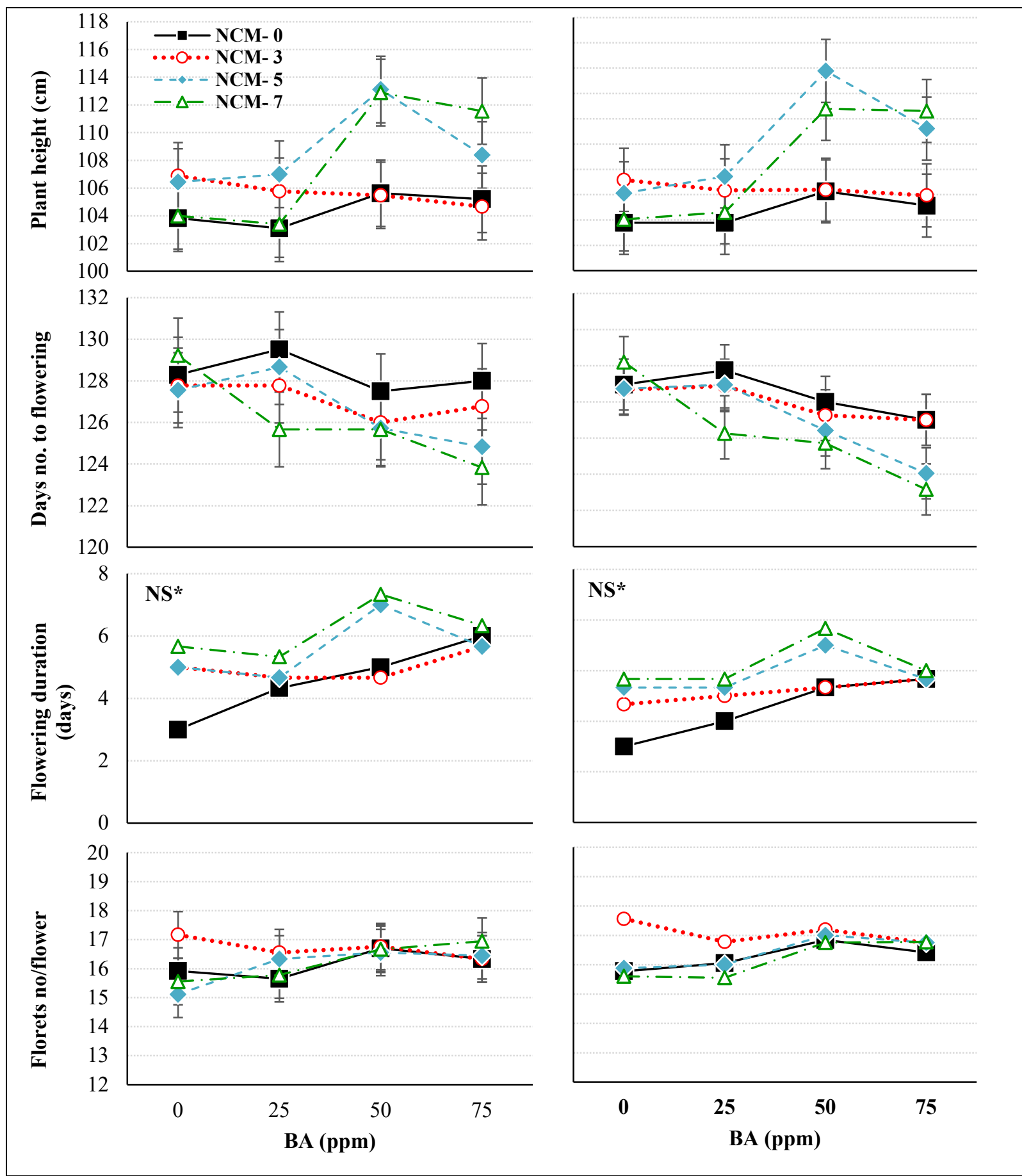

Fig. 1. Effect of BA and nano- carbon material (NCM) at certain concentrations on growth of gladiolus plants in terms of plant height $(\mathrm{cm})$, number of days to flowering, duration of flowering season and number of florets/ flower during two growing seasons. All experiments were performed in triplicate, and the error bars represent LSD values at $p \geq 0.05, * N S$ denotes non-significant differences using ANOVA. 


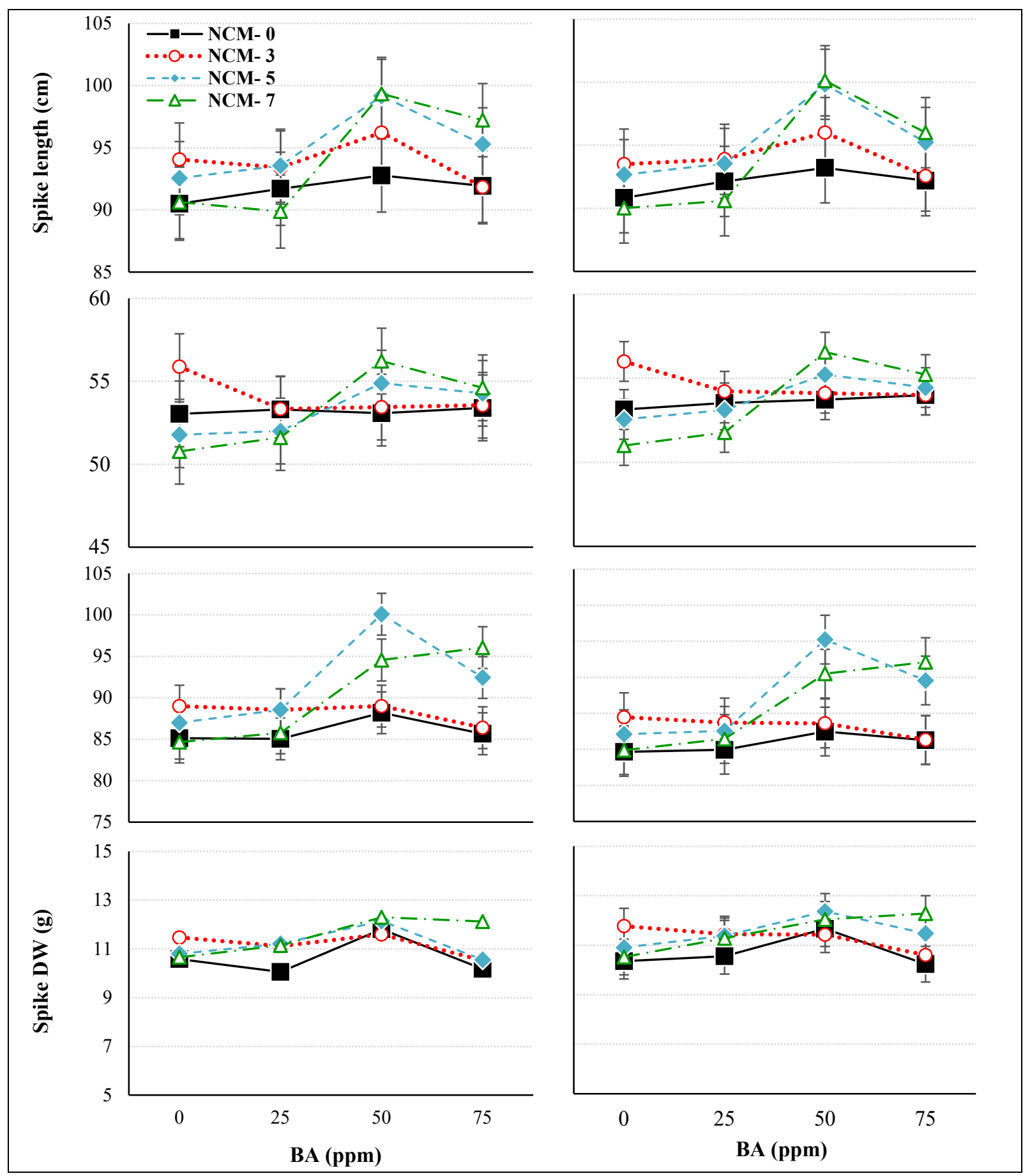

Fig. 2. Effect of BA and nano- carbon material (NCM) at certain concentrations on growth of gladiolus plants in terms of spike length $(\mathrm{cm})$, rachis length $(\mathrm{cm})$ and spike fresh and dry weights (g) during two growing seasons. All experiments were performed in triplicate, and the error bars represent LSD values at $p \geq 0.05, *$ NS denotes nonsignificant differences using ANOVA. 


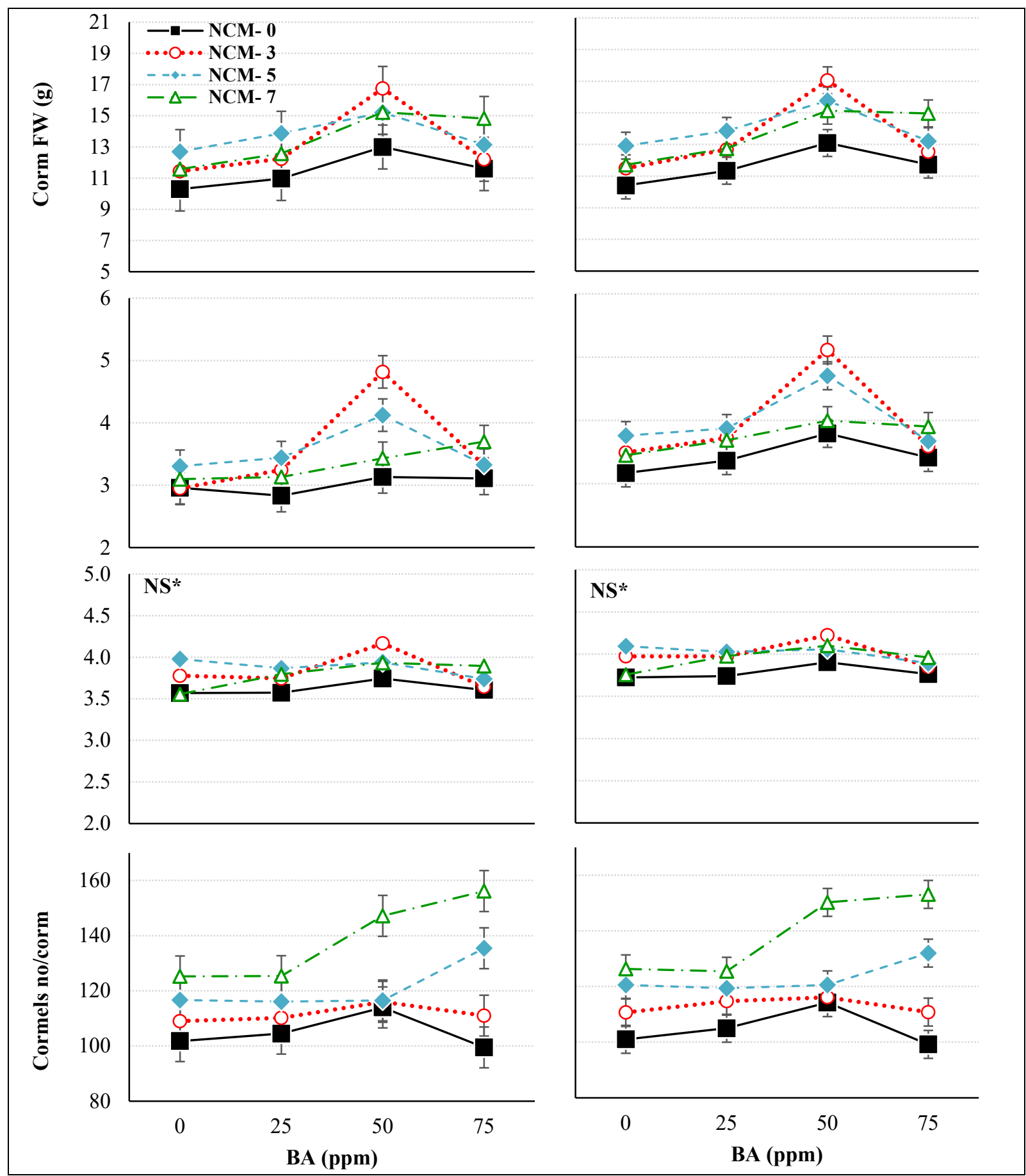

Fig. 3. Effect of BA and nano- carbon material (NCM) at certain concentrations on growth of gladiolus plants in terms of crom fresh and dry weights (g), corm diameter and number of cormels/ corm during two growing seasons. All experiments were performed in triplicate, and the error bars represent LSD values at $p \geq 0.05, * N S$ denotes non-significant differences using ANOVA. 


\section{O.H. Tawfik and O.H.M. Ibrahim}

relationships in all cases except for the number of days to flowering, which was negatively correlated with all the traits (Table, 2). This relationship was very high ( $\mathrm{r}$ $\geq 0.90$ ) between plant height and each of spike length and florets number/spike as well as spike length and florets number/spike. The correlation was medium to high between plant height and all flowering traits in addition to corm FW and the number of cormels/ corm. All flowering traits correlated with each other in a medium $(\mathrm{r}=5.0$ to 7.0$)$ to a high ( $r=7.0$ to 9.0) relationship. Flowering duration, spike length, spike FW and the number of florets/spike showed medium to high correlation with corm FW and number of cormels. Both spike diameter and corm diameter were excluded from the correlation matrix since they showed nonsignificant variation using ANOVA.

Principal component analysis (PCA) of the measured traits:

Out of the 11 components calculated by the PCA analysis, the first three components had eigenvalues $\geq 1$. The cumulative variance explained by the first two principal components, $\mathrm{PC} 1$ and $\mathrm{PC} 2$, accounts for $73.3 \%$ of the total variance of the data as illustrated in the PCA monoplot (Fig., 4).
PC1 shows high loading of plant height, spike length, florets number/spike, spike DW and corm FW Table, 3). It indicates that these traits have significant contributions to the first PC. Either these elements have a common ground of variance or they are inter-correlated. The high loadings of spike length, florets number/spike, spike DW are attributed to the fact that these are the main characteristics of high-quality gladiolus flowers. High loading of plant height indicates the importance of vegetative growth as a determinative factor for flowering traits in gladiolus. The fresh weight of the produced corm has a strong positive relationship with the previously mentioned traits as evident by the high loading of corm FW.

PCA results confirmed those obtained by Pearson's correlation coefficient, as all traits showed a positive correlation with each other except for the number of days to flowering, which had a negative correlation with the other traits. The arrows of six variables are clustered together, i.e. corm FW, plant height, florets number/ spike, spike DW, spike length and corm DW, indicating a strong correlation among them.

Table 2. Pearson's correlation coefficients among all traits across two growing seasons.

\begin{tabular}{|c|c|c|c|c|c|c|c|c|c|c|}
\hline Characters & 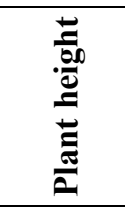 & 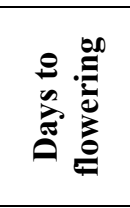 & 总 & 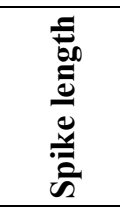 & 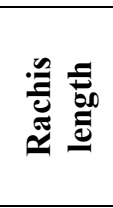 & 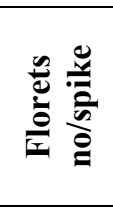 & $\begin{array}{l}3 \\
\frac{0}{2} \\
\frac{1}{2}\end{array}$ & $\begin{array}{l}3 \\
0 \\
0 \\
\frac{8}{2} \\
\frac{1}{2}\end{array}$ & ن & נa \\
\hline Days to flowering & $-0.65^{* *}$ & - & & & & & & & & \\
\hline Flowering duration & $0.73 * *$ & $-0.55 * *$ & - & & & & & & & \\
\hline Spike length & $0.91^{* *}$ & $-0.58 * *$ & $0.67 * *$ & - & & & & & & \\
\hline Rachis length & $0.69 * *$ & $-0.45^{* *}$ & $0.41 * *$ & $0.76^{* *}$ & - & & & & & \\
\hline Florets no./spike & $0.97 * *$ & $-0.71 * *$ & $0.68 * *$ & $0.90 * *$ & $0.67 * *$ & - & & & & \\
\hline Spike FW & $0.52 * *$ & $-0.37^{*}$ & 0.29 & $0.62 * *$ & $0.80 * *$ & $0.55 * *$ & - & & & \\
\hline Spike DW & $0.79 * *$ & $-0.54 * *$ & $0.53 * *$ & $0.77 * *$ & $0.57 * *$ & $0.80 * *$ & $0.62 * *$ & - & & \\
\hline Corm FW & $0.67 * *$ & $-0.57 * *$ & $0.59 * *$ & $0.79 * *$ & $0.36^{*}$ & $0.68 * *$ & $0.46^{* *}$ & $0.72 * *$ & - & \\
\hline Corm DW & $0.48 * *$ & -0.31 & $0.37 *$ & $0.61 * *$ & 0.28 & $0.49 * *$ & 0.44 & $0.54 * *$ & $0.85^{* *}$ & - \\
\hline Cormels no./corm & $0.65 * *$ & $-0.68 * *$ & $0.64 * *$ & $0.55 * *$ & 0.29 & $0.63 * *$ & 0.17 & $0.61 * *$ & $0.55^{* *}$ & 0.26 \\
\hline
\end{tabular}

*, ** Significant at the 0.05 and 0.01 probability levels, respectively. 


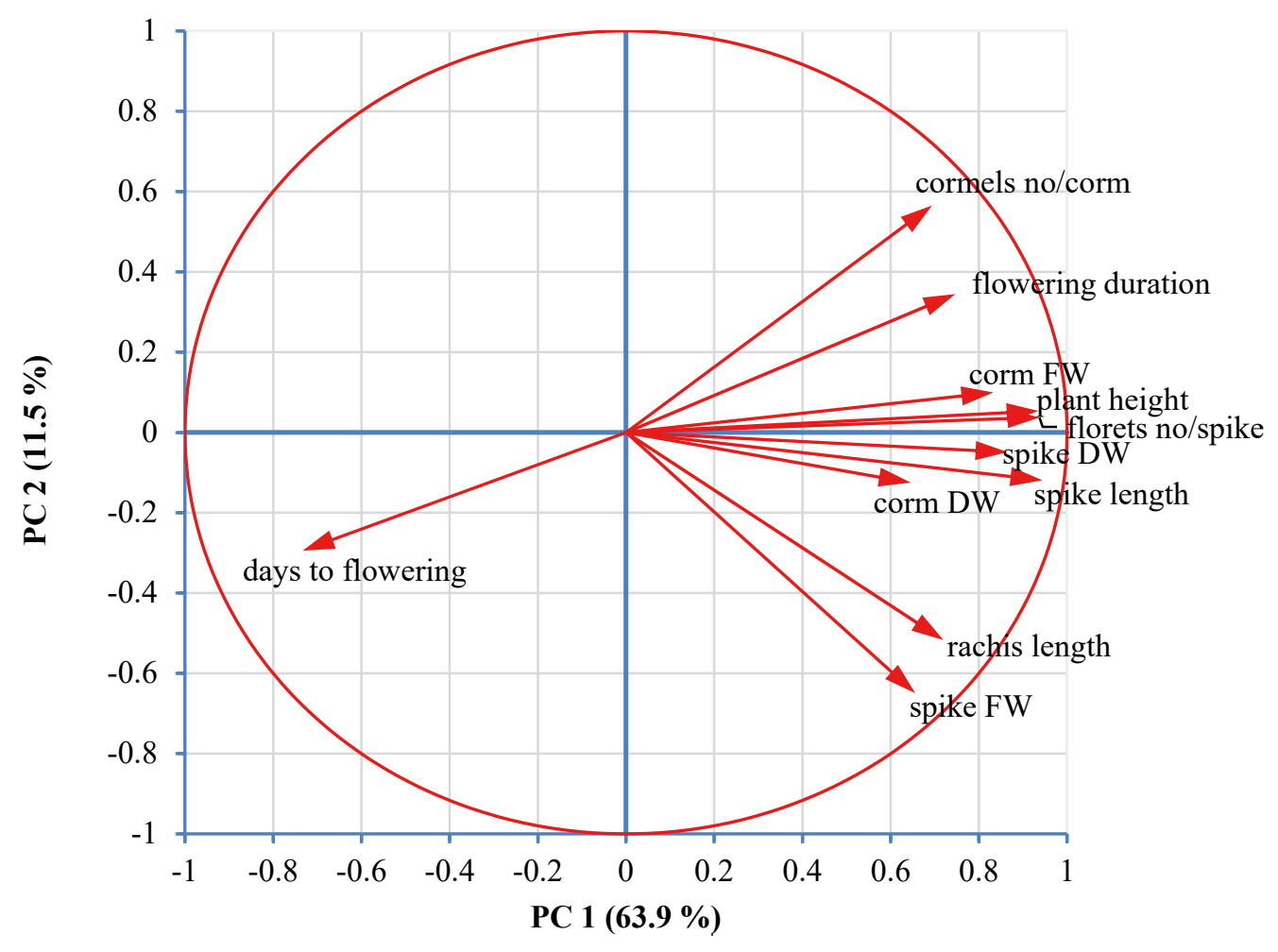

Fig. 4. Monoplot of principal component analysis (PCA) for all traits across two growing seasons. The circle has a perfect correlation value (1.0), and arrow lengths are proportional to the correlation coefficient for each variable.

Table 3. Loadings of gladiolus traits in PCA components with eigenvalue more than one.

\begin{tabular}{lccc}
\hline \multicolumn{1}{c}{ Characters } & \multicolumn{3}{c}{ Component } \\
\hline Plant height & $\mathbf{1}$ & $\mathbf{2}$ & $\mathbf{3}$ \\
Days to flowering & 0.353 & 0.048 & 0.158 \\
Flowering duration & -0.277 & -0.262 & -0.211 \\
Spike length & 0.282 & 0.307 & 0.084 \\
Rachis length & 0.356 & -0.106 & -0.018 \\
Florets no./spike & 0.271 & -0.460 & 0.368 \\
Spike FW & 0.354 & 0.033 & 0.140 \\
Spike DW & 0.247 & -0.579 & 0.076 \\
Corm FW & 0.326 & -0.044 & -0.051 \\
Corm DW & 0.314 & 0.089 & -0.489 \\
Cormels no./corm & 0.243 & -0.111 & -0.703 \\
\hline
\end{tabular}

All variables except the number of days to flowering point towards high values of PC1 (explaining $63.9 \%$ of the variance) denoting a positive correlation between these variables and $\mathrm{PC} 1$. Therefore, $\mathrm{PC1}$ at high values is expected to entail a better performance of gladiolus in terms of these traits. However, we expect gladiolus plants with high PC2 (explaining only 11.5 of the variance) to have high values of plant height, flowering duration, florets number/ spike, corm FW and number of cormels/ corm, but lower values of the other traits since they are negatively correlated with PC2. 


\section{O.H. Tawfik and O.H.M. Ibrahim}

\section{DISCUSSION}

Like many other flowering bulbs cultivated in Egypt, high-quality gladiolus corms are annually imported from abroad, mostly from the Netherlands. With the recent unprecedented global spread of COVID-19, questions regarding the pandemic's impact on exports and imports have become hot topics. This led to raising the prices of corms or the unavailability of the imported corms, which encouraged us to study some innovative factors that may help produce the corms locally including the application of graphene-based nanomaterials and 6Benzylaminopurine.

The current study revealed that the vegetative and flowering growth and corm production parameters (except spike diameter and corm diameter) showed a significant variation in response to the applied treatments. The PCA and correlation analyses between the tested parameters help explain the relationship between parameters and predict the performance of gladiolus in terms of flowering and corm production. The correlation analysis showed that the quality of flowering traits could be efficiently predicted by other plant characters. Plant height is a very good predictor for the behavior of flowering traits including spike length and the number of florets/spike (with a highly statistically significant correlation). Likewise, the correlation results facilitate the prediction of corm productivity performance through its positive correlation with plant height and some flowering characteristics such as spike length and florets number/spike. Calculation of PCA could also help entail a better performance of gladiolus by the high values of both PC1 and PC2.

Enhancement of vegetative and flowering growth and corm production parameters was feasible in response to the application of nano-carbon. Both the medium and the high concentrations ( 5 and 7 $\mathrm{g} / \mathrm{l}$ ), respectively, were the most effective treatments inducing the best results. The promoting effect of nano-carbon on plant height and fresh and dry matter was reported by Younes et al. (2019) on eggplant and pepper. In our study, the same concentrations of nano-carbon also accelerated flowering significantly, which is consistent with the findings of other investigators such as Lahiani et al. (2015), Mohamed et al. (2018) and Wang et al. (2018). They found that the application of nano-carbon promoted the growth of the root system, the net photosynthetic rate and chlorophyll content. In the same context, Ruiz et al. (2011) attributed the effect of nano-carbon to its role in activating plant growth and productivity through triggering cell division and proliferation, which is accompanied by an activation of photosynthetic activities. The reason may lie in the localization of nanocarbon materials inside the chloroplast, which facilitates carbon fixation and thus induces the sugar metabolism in addition to allowing the plants to harvest more light energy (Siddiqui et al., 2015). The increase in the rate of photosynthesis leads to the accumulation of carbohydrates in the form of giant starch grains in the chloroplast, and therefore the plants respond to that by increasing the number of mitochondria (Giraldo et al., 2014 and Chichiricco and Poma, 2015). Moreover, Akhavan et al. (2011) proposed an explanation relying on the adsorption of nano-carbon around cell walls due to the interaction between the amino groups on biological cells and the nano-carbon particles.

Increment in some gladiolus growth characters by increasing nano-carbon concentration noticed in the current study contradicts the findings of some authors on other plant species such as maize, which showed inhibition in growth by increasing nano-carbon. Treatment with graphene oxide modulates the root growth and affects ABA and IAA biosynthesis and concentration (Yin et al., 2018). However, some other studies, for example, Zhao et al. (2015), revealed non-significant effects for graphene oxide at concentrations ranging from 10-1000 mg/1 on vegetative and flowering growth of Arabidopsis. In another study, also the lower concentration (0.1-10 $\mathrm{mg} / \mathrm{l})$ had no 
significant effects on wheat growth $(\mathrm{Hu}$ et al., 2014). A different effect was reported by Anjum et al. (2014), where plant growth was inhibited by both the lowest (100 and 200 $\mathrm{mg} / \mathrm{l})$ and the highest concentrations (1600 $\mathrm{mg} / \mathrm{l})$ while improved by the other concentrations in between (400 and 800 $\mathrm{mg} / \mathrm{l})$. All these studies and others confirm the fact that the effect of graphene oxide depends mainly on the concentration applied and the plant species (Begum et al., 2011).

The influence of BA on the growth of gladiolus has been studied for a long time, yet its interaction effect with nano-carbon investigated in the current study is a new idea. The application of BA in the current experiment positively affected the growth and corm productivity of gladiolus. This effect significantly increased as the concentration of BA was raised to $50 \mathrm{mg} / \mathrm{l}$ attaining the highest values of plant height, duration of the flowering season, spike and rachis lengths, number of florets per spike, spike FW and DW, and corm FW and DW. Moreover, the earliest flowering and the highest number of cormels/corm were induced by the highest concentration of BA (75 mg/l).

The promoting effect of BA has been reported in several previous studies in a concentration ranging from $25-150 \mathrm{mg} / \mathrm{l}$, which is quite similar to that employed in the current study. This effect was recorded on the sprouting percentage of corms using BA at $25 \mathrm{mg} / 1$ (Ram et al., 2002). Application of cytokinins including BA affects the vegetative growth of plants in terms of inducing multiple shooting and decreasing plant height. This has been proved in gladiolus by several authors such as Khan et al. (2013), Richards and Wilkinson (1984), Khan et al. (2011), Roy et al. (2017), Maurya and Nagda (2002) since BA, like other cytokinins, characteristically causes more splitting and cell division (Baskaran et al., 2009). Induction of multiple sprouting by BA leads to the formation and the acceleration of multiple corms or cormels production (Tawar et al., 2007; Richards and
Wilkinson, 1984; Khan et al., 2011; Roy et al., 2017; Khan et al., 2013), which is consistent to our results. A similar trend was reported by Singh et al. (2020), Mahesh and Misra (1993). Some authors such as Ram et al. (2002) stated that the promoting effect of BA on developing corm and cormels at the expense of flower spike is probably the reason for the increase in the number of corms and cormels and poor quality flower spikes. Ragini et al. (2019) reported that tuberization is indirectly affected by the enhancement in starch deposition due to the activation of starch synthesizing enzymes. Additionally, cytokinins are thought to be involved in the initial creation of the strong tuber sink and promoting the mobilization of carbohydrates.

\section{CONCLUSION}

The current study proved the potential of graphene-based nanomaterials to enhance the growth and corm production of gladiolus 'White Prosperity'. The results demonstrated that the combination of the medium or the high concentrations of BA (50 and $75 \mathrm{mg} / \mathrm{l}$ ), with those of nano-carbon (5 and $7 \mathrm{~g} / \mathrm{l}$ ) promoted good vegetative and flowering growth of gladiolus. The lowest concentration of nano-carbon $(3 \mathrm{~g} / \mathrm{l})$ alone or in combination with BA at $50 \mathrm{mg} / 1$ induced the highest number of florets per spike and the heaviest new corm. Various relationships between growth parameters of gladiolus were investigated using Pearson's product correlation and PCA analysis. Our findings provide evidence that nano-carbon positively affected the flowering and corm production of gladiolus that may be applicable for other important flower bulb species.

\section{REFERENCES}

Akhavan, O.; Ghaderi, E. and Esfandiar, A. (2011). Wrapping bacteria by graphene nanosheets for isolation from environment, reactivation by sonication, and inactivation by near-infrared irradiation. Journal of Physical Chemistry B, 115: 6279-6288. 


\section{O.H. Tawfik and O.H.M. Ibrahim}

Ali, G.A.; Makhlouf, S.A.; Yusoff, M.M. and Chong, K.F. (2015). Structural and electrochemical characteristics of graphene nanosheets as supercapacitor electrodes. Reviews on Advanced Materials Science, 41(1):35-43.

Analytical Software. (2008). Statistix Version 8.1 (8.1). Analytical Software, Tallahassee, Florida, USA.

Anjum, N.A.; Singh, N.; Singh, M.K.; Sayeed, I.; Duarte, A.C.; Pereira, E. and Ahmad, I. (2014). Single-bilayer grapheneoxide sheet impacts and underlying potential mechanism assessment in germinating faba bean (Vicia faba L.). Science of the Total Environment, 472: 834-841.

Baskaran, V.; Misra, R.L. and Abirami, K. (2009). Effect of plant growth regulators on corm production in gladiolus. Journal of Horticultural Sciences, 4(1):78-80.

Begum, P.; Ikhtiari, R. and Fugetsu, B. (2011). Graphene phytotoxicity in the seedling stage of cabbage, tomato, red spinach and lettuce. Carbon, 49:39073919.

Benschop, M.; Kamenetsky, R.; Le Nard, M.; Okubo, H. and De Hertogh, A. (2010). The global flower bulb industry: production, utilization, research. Horticultural Reviews, 36(1):1-115.

Black, C.A.; Evans, D.D.; White, J.I.; Ensminger, L.E. and Clark, F.E. (1965). Methods of Soil Analysis, Part 2: Chemical and Microbiological Properties. American Society of Agronomy, Madison Inc., Madison, 1569 p.

Chakravarty, D.; Erande, M.B. and Late, D.J. (2015). Graphene quantum dots as enhanced plant growth regulators: effects on coriander and garlic plants. Journal of the Science of Food and Agriculture, 95(13):2772-2778.

Chichiricco, G. and Poma, A. (2015). Penetration and toxicity of nanomaterials in higher plants. Nanomaterials, 5:851873.

Giraldo, J.P.; Landry, M.P.; Faltermeier, S.M.; McNicholas, T.P.; Iverson, N.M.; Boghossian, A.A.; Reuel, N.F.; Hilmer, A.J.; Sen,F. and Brew, J.A. (2014). Plant nanobionics approach to augment photosynthesis and biochemical sensing. Nature Materials, 13: 400-408.

Gomez, K.A. and Gomez, A.A. (1984). Statistical Procedures for Agricultural Research $\left(2^{\text {nd }}\right.$ ed.). John Wiley and Sons Inc., $680 \mathrm{p}$.

Hu, W.; Peng, C.; Luo, W.; Lv, M.; Li, X.; Li, D.; Huang, Q. and Fan, C. (2010). Graphene-based antibacterial paper. ACS Nano, 4(7):4317-4323.

Hu, X.; Kang, J.; Lu, K.; Zhou, R.; Mu, L. and Zhou, Q. (2014). Graphene oxide amplifies the phytotoxicity of arsenic in wheat. Scientific Reports, 4:1-10. https://doi.org/10.1038/srep06122

Jackson, M.L. (1973). Soil Chemical Analysis. Printice-Hall of India, Privat Limited, $489 \mathrm{p}$.

Kabiri, S.; Degryse, F.; Tran, D.N.H.; da Silva, R.C.; McLaughlin, M.J. and Losic, D. (2017). Graphene oxide: A new carrier for slow release of plant micronutrients. ACS Applied Materials and Interfaces, 9(49):43325-43335.

Khan, F.N.; Rahman, M.M; and Hossain, M.M. (2013). Effect of benzyladenine and gibberellic acid on dormancy breaking, growth and yield of gladiolus corms over different storage periods. Journal of Ornamental and Horticultural Plants, 3(1): 59-71.

Khan, F.N.; Rahman, M.M.; Hossain, M.M. and Hossain, T. (2011). Effect of benzyladenine and gibberellic acid on dormancy breaking and growth of gladiolus cormels. Thailand Journal of Agricultural Science, 44: 165-174.

Khodakovskaya, M.V; De Silva, K.; Biris, A.S.; Dervishi, E. and Villagarcia, $\mathrm{H}$. 
(2012). Carbon nanotubes induce growth enhancement of tobacco cells. ACS Nano, 6(3):2128-2135.

Lahiani, M.H.; Chen, J.; Irin, F.; Puretzky, A.A.; Green, M.J. and Khodakovskaya, M.V. (2015). Interaction of carbon nanohorns with plants: uptake and biological effects. Carbon, 81: 607-619.

Lepcha, B.; Nautiyal, M.C. and Rao, V.K. (2007). Variability studies in gladiolus under mid hill conditions of Uttarakhand. Journal of Ornamental Horticulture, 10(3): 169-172.

Mahesh, K.S. and Misra, R.L. (1993). Effect on growth regulators on gladiolus. Journal of Ornamental Horticulture, $1(2): 12-15$.

Maurya, R.P. and Nagda, C.L. (2002). Effect of growth substances on growth and flowering of gladiolus (Gladiolus grandiflorus L.) cv. Friendship. Haryana Journal of Horticultural Sciences, 31(3/4):203-204.

Mohamed, A.M.; Hashim, F.A.; Alghuthaymi, A.M.; Kamel, A. and AbdElsalam, K.A. (2018). Nano-carbon: plant growth promotion and protection. In: Abd-Elsalam, R. and Prasad K. (eds.), Nanobiotechnology Applications in Plant Protection, Nanotechnology in the Life Sciences Springer, Cham., pp. 155-188.

Novoselov, K.S.; Fal, V.I.; Colombo, L.; Gellert, P.R.; Schwab, M.G. and Kim, K. (2012). A roadmap for graphene. Nature, 490: 192-200.

Park, S.; Choi, K.S.; Kim, S.; Gwon, Y. and Kim, J. (2020). Graphene oxide-assisted promotion of plant growth and stability. Nanomaterials, 10(4):1-11. https://doi.org /10.3390/nano 10040758

Ragini, B.K.; Chandrashekar, S.Y.; Hemla, N.B.; Shivaprasad, M. and Ganapathi, M. (2019). Effect of cytokinins (benzyl adenine and kinetin) on bulbous flower crops: A review. International Journal of Chemical Studies, 7(5):2618-2622.
Ram, R.; Mukherjee, D. and Manuja, S. (2002). Plant growth regulators affect the development of both corms and cormels in gladiolus. HortScience, 37(2): 343344.

Richards, D. and Wilkinson, R.I. (1984). Effect of manual pinching, potting-on and cytokinins on branching and flowering of Camellia, Rhododendron and Rosa. Scientia Horticulturae, 23(1): 75-83.

Roy, S.; Fatmi, U.; Mishra, S. and Singh, R. (2017). Effect of pre-plant soaking of corms in growth regulators on sprouting, vegetative growth and corm formation in gladiolus (Gladiolus grandiflorus L.). Journal of Pharmacognosy and Phytochemistry, 6(5):1135-1138.

Ruiz, O.N.; Fernando, K.A.S.; Wang, B.; Brown, N.A.; Luo, P.G.; McNamara, N.D.; Vangsness, M.; Sun, Y.P. and Bunker, C.E. (2011). Graphene oxide: a nonspecific enhancer of cellular growth. ACS Nan, 5: 8100-8107.

Serag, M.F.; Kaji, N.; Tokeshi, M. and Baba, Y. (2015). Carbon nanotubes and modern nanoagriculture. In: Siddiqui, M.; AlWhaibi, M. and Mohammad F. (eds.), Nanotechnology and Plant Sciences, Springer, pp. 183-201.

Shareena, T.P.D.; McShan, D.; Dasmahapatra, A.K. and Tchounwou, P.B. (2018). A review on graphene-based nanomaterials in biomedical applications and risks in environment and health. Nano-Micro Letters, 10(3):1-34.

Siddiqui, H.M.; Al-Whaibi, H.M.; Firoz, M. and Al-Khaishany, Y.M. (2015). Role of Nanoparticles in Plants. In: Siddiqui, M.H.; Al-Whaibi, M.H. and Firoz, M. (eds.), Nanotechnology and Plant Sciences Nanoparticles and Their Impact on Plants, Springer International Publishing, pp. 19-35.

Singh, A.R.; Kumar, S. and Wasnik, S.B. (2020). Analysis of effect of GA3, NAA and $\mathrm{BA}$ on growth, flowering and corm 


\section{O.H. Tawfik and O.H.M. Ibrahim}

production in Gladiolus cv. White Prosperity. Journal of Pharmacognosy and Phytochemistry, 9(4): 234-240.

Taha, R.A. (2016). Nano-carbon applications for plant. Advances in Plants and Agriculture Research, 5(2):1-2. http://dx.doi.org/10.15406/apar.2016.05. 00172

Tawar, R.V; Sable, A.S.; Kakad, G.J.; Hage, N.D., and Ingle, M.B. (2007). Effect of growth regulators on corms and cormels production of Gladiolus cv. Jester. Annals of Plant Physiology, 21: 257-258.

Wang, G.; Xiao, Y.; Peng, F.; Zhang, Y.; Gao, H.; Sun, X. and He, Y. (2018). Effects of urea application combined with different amounts of nano-carbon on plant growth along with nitrogen absorption and utilization in young peach trees. Scientia Agricultura Sinica, 51(24): 4700-4709.
Yin, L.; Wang, Z.; Wang, S.; Xu, W. and Bao, H. (2018). Effects of graphene oxide and/or $\mathrm{Cd}^{2+}$ on seed germination, seedling growth, and uptake to $\mathrm{Cd}^{2+}$ in solution culture. Water, Air, and Soil Pollution, 229:1-12. https://doi.org/10. 1007/s11270-018-3809-y

Younes, N.A.; Dawood, M.F.A. and Wardany, A.A. (2019). Biosafety assessment of graphene nanosheets on leaf ultrastructure, physiological and yield traits of (Capsicum annuum L.). Chemosphere, 228:318-327. https:// doi.org/10.1016/j.chemosphere.2019.04.0 97

Zhao, S.; Wang, Q.; Zhao, Y.; Rui, Q. and Wang, D. (2015). Toxicity and translocation of graphene oxide in Arabidopsis thaliana. Environmental Toxicology and Pharmacology, 39:145156.

\section{استخدام معاملة مبتكرة من المواد النانوية الكربونية والبنزيل أدينين لتحسين الإزهار وإنتاج الكورمات

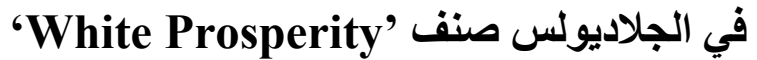

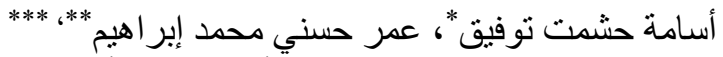

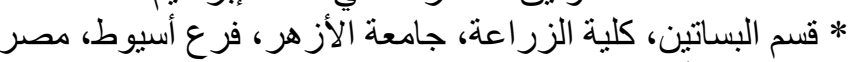$$
\text { ** قسم زر اعة المناطق الجافة، كلية الأرصاد و البيئة وزر اعة المناطق الجافة، جامعة الملك عبد العزيز، المملكة العربية }
$$

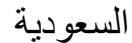$$
\text { **** قسم نباتات الزينة وتنسيق الحدائق، كلية الزر اعة، جامعة أسيوط، مصر }
$$

للمواد النانوية الكربونية قدرة على تحسين إنتاج أزهار القطف بما في ذلك إمكانية إنتاج كورمات جلاديولس عالية

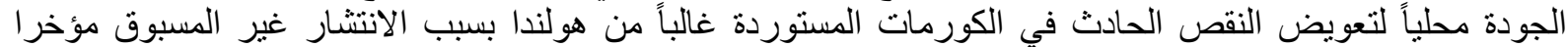

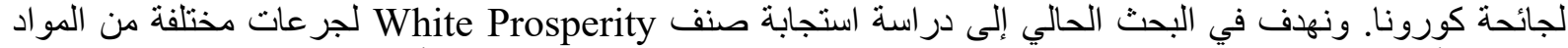

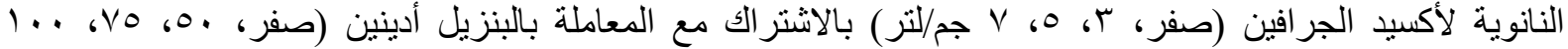

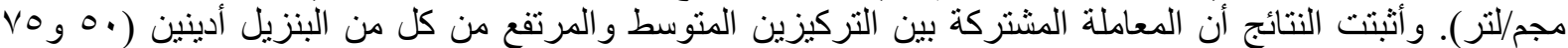

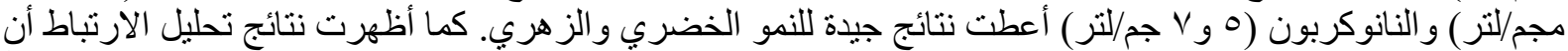

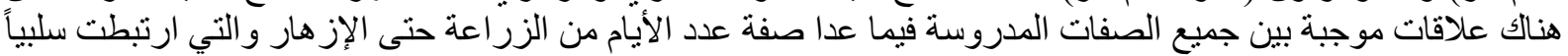

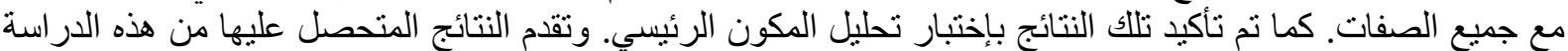

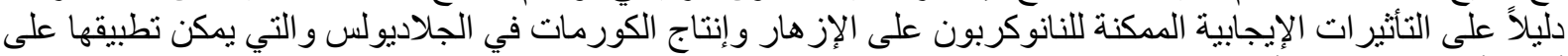
أنو اع أخرى هامة من أزهار القطف.
} 